\title{
Effects of Cyclooxygenase and Lipoxygenase Inhibitors on the Proliferation of Colon Cancer Cells and Their Production of Eicosanoids
}

\author{
Hyun Sook Lee, Eun Ji Kim, Yoon Sin Oh, Han Jin Cho and Jung H.Y. Park \\ Division of Life Sciences, Hallym University, Chunchon, Korea
}

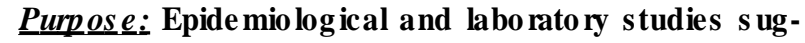
gest that nons teroidal antiinflammatory drugs (NSAIDs) reduce the ris $k$ of colon cancer and that the inhibition of colon cancer is mediated through modulation of eicosano id production. The pres ent study examined the effect of cyclooxygenase (COX) and lipoxygenase (LOX) inhibitors on colon cancer cell growth and prostaglandin $\mathrm{E}_{2}$ $\left(\mathbf{P G E}_{2}\right)$ or le ukotrie ne $\mathrm{B}_{4}\left(\mathrm{LTB}_{4}\right)$ secretion by these cells.

Materials and Methods: The human colon adenocarcinoma cell lines, Caco-2 and HT-29 cells, were cultured in serum-free medium with various concentrations of indomethacin, piroxicam or esculetin in the presence of $0.15 \mu \mathrm{M}$ or $10 \mu \mathrm{M}$ linole ic acid. Cell number was estimated by MTT assay and $\mathrm{PGE}_{2}$ and $\mathrm{LTB}_{4}$ were analyzed by enzyme immunoassay.

Results: The NSAIDs inhibited cell proliferation in a concentration-dependent manner. However, the potency and efficacy of each drug varied in the two cell lines. In Caco-2 cells, the effect of esculetin was higher than that of indomethacin, and piroxicam had no effect. In HT-29 cells, only indo methac in s ig nificantly inhibited cell pro life ration. All three age nts inhibited $\mathrm{PGE}_{2}$ secretion in

\section{서 론}

대장암은 서구선진국에서 발생빈도가 높은 암으로서, 미 국에서는 15 만 명의 대장암 환자가 해마다 새로 생기고 6 만명 정도가 또 매년 대장암으로 사망한다(1). 이것은 전체 암 사망률의 $15 \%$ 를 차지하는 매우 높은 수치다. 반면에 우

Correspondence: Jung H.Y. Park, Division of Life Sciences, Hallym University, 1 Okchon-dong, Chunchon 200-702, Korea. (Tel) 033-240-1477, (Fax) 033-256-0199, (E-mail) jyoon @ hallym.ac.kr

This work was supported by grant No. (R01-1999-00166) from the Korea Science \& Engineering Foundation and a grant of the Korea Science and Engineering Foundation RRC project.

Received August 3, 2001, Accepted October 5, 2001 a dose-de pe nde nt manner; the effect of indomethac in was highest and that of es culetin lowest. The secretion of LTB was increased by indomethacin and piroxicam but decreased by esculetin. The effects of these drugs on cell pro life ration and eicosano id secretion we re not influe nced by linoleic acid concentrations in the culture media. Ne ithe r exoge no us $\mathrm{PGE}_{2}$ nor $\mathrm{LTB}_{4}$ affected cell pro life ration. The res ults of Pearson correlation analys es revealed that changes in cell proliferation were somewhat related to both concentrations of NSAIDs in the culture medium and production of $\mathrm{PGE}_{2}$ and $\mathrm{LTB}_{4}$.

Conclusion: The present data sugges ts that the antiprolife rative effect of NSAIDs may not be entirely attributed to changes in the production of $\mathrm{PGE}_{2}$ and/or $\mathrm{LTB}_{4}$ in the two colon cancer cell lines. These NSAIDs may inhibit cell pro life ration large ly inde pe nde nt of the ir ability to modulate eicos ano id synthes is. (Cancer Res earch and Treatment 2001;33:404-413)

Key Words : Colon neoplas m, Cyclooxyge nase inhibitor, Lipoxygenase inhibitor, Eicos anoid

리나라, 일본, 남미, 아프리카는 대장암 발생률이 상대적으 로 선진국보다는 낮지만 우리 나라에서도 현재 네 번째로 흔한 종양으로서 빠른 속도로 늘고 있는 추세이다(2).

역학조사와 실험논문들에 의해 대장암 발생은 식이요 인과 밀접한 상관관계를 가지고 있음이 이미 증명되었다. 우리 나라의 대장암 발생빈도 증가도 식사형태의 서구화 에 따른 지방섭취 증가와 밀접한 관련이 있다. 우리 나라 의 국민영양조사 결과를 보면 에너지 중 지방의 구성비율 은 1981년에 $9.0 \%$ 이던 것이 1998년에는 $19 \%$ 로 증가하였 다. 이는 미국을 비롯한 서구 선진국의 $30 \%$ 이상 되는 수 치에 비하면 낮은 수준이긴 하나 식이 지방과 밀접한 관 계가 있는 순환계 질병과 악성 종양 발생이 지방의 구성 비 증가에 따라 증가하고 있으며 이로 인한 사망률도 증 가하고 있다(3).

최근 NSAIDs가 대장암과 상관관계가 있다는 역학조사 
가 보고되었다(4,5). NSAIDs가 대장암 발생을 억제하는 기 전에 대해서는 아직 분명하게 밝혀진 바가 없다. 단, NSAIDs가 아라키돈산의 대사에 영향을 미쳐 암발생을 억 제할 가능성이 제시되었다. NSAIDs가 cyclooxygenase (COX) 와 lipoxygenase (LOX)의 작용을 억제함으로서 이에 따라 eicosanoid의 생성이 저해되어 암발생이 억제된다는 가설 이다. Eicosanoid는 세포증식, 종양 성장, 면역반응(6,7)에 영향을 미치는 물질이기 때문이다.

$\mathrm{COX}$ 는 아라키돈산이 PGs과 다른 eicosanoid로 전환되 는 과정의 속도제한효소 중의 하나이며 COX-1과 COX-2 의 두 가지 이성체가 발견되었다. COX-1과 COX-2 둘 다 $\mathrm{PG}$ 형성을 촉매하지만 생리적인 기능은 다른 것으로 보 인다. COX- 1 은 대부분의 조직에서 일정하게 발현되어 세 포의 항상성을 유지하는 기능이 있는 반면, $\mathrm{COX}-2$ 는 정상 조직에서는 검출이 안 되다가 여러 가지 성장인자들이나 종양 촉진제 $(6,7)$, 활성 산소 중간대사물들(8)에 의한 자극 과 면역반응에서 재빨리 발현된다. 사람과 동물을 대상으 로 한 연구에서 COX-2의 발현은 세포증식, 분열, 그리고 몇몇 조직의 암과 상관관계가 있음이 밝혀졌다 $(9,10)$. 동 물 모델에서 $\mathrm{COX}-2$ 저해제 투여로 대장의 손상이 감소되 었으며(11), 사람에서도 대장, 전립선과 식도암의 발생을 억제하였다(12). $\mathrm{PGE}_{2}$ 는 $\mathrm{COX}-2$ 의 주요 산물로서 bcl-2 발 현을 촉진하고 apoptosis를 저해하는 반면, COX-2 저해제 는 apoptosis를 촉진하는 것으로 보고되었다 $(12,13)$.

LOX는 아라키돈산으로부터 leukotriene (LT)과 hydroxyeicosanoic acid (HETE)를 생성시키는 효소이다. Bortuzzo등 (14)은 HT-29와 HCT- 15 의 두 대장암 세포의 증식이 $\mathrm{LTB}_{4}$ 와 $12(\mathrm{R})-\mathrm{HETE}$ 의 양이 증가할수록 증가한다고 보고했다. 또한 같은 연구에서 5-LOX 저해제인 BWA4C와 BWB70C 를 $10 \mu \mathrm{M}$ 이하로 첨가한 결과 세포증식이 억제되었다.

따라서 NSAIDs는 아라키돈산 대사의 경로 중 COX 또 는 LOX의 활성 변화를 유도함으로써 암세포 증식의 억제 또는 apoptosis 증가 효과를 나타내는 것으로 기대된다. 본 연구에서는 두 가지의 다른 대장암 세포주를 대상으로 $\mathrm{COX}$ 저해제 또는 $\mathrm{LOX}$ 저해제가 세포 증식과 $\mathrm{PGE}_{2}$ 와 $\mathrm{LTB}_{4}$ 생성량에 미치는 영향을 살펴봄으로써 암세포의 증 식과 eicosanoid와의 상관관계를 알아보고자 실행되었다.

\section{재료 및 방법}

\section{1) 실험재료}

본 연구에 사용한 인간의 대장암 세포인 Caco-2, HT-29 cell은 American Type Culture Collection (Rockville, MD)에 서 구입하였다. 세포 배양에 사용한 Dulbecco's modified
Eagle's medium/Nutrient Mixture Ham's F12 (DMEM/F12)와 fetal bovine serum (FBS), trypsin-EDTA, penicillin-streptomycin, transferrin, selenium은 Gibco-BRL (Gaitherburg, MD)에 서 구입하였다. Linoleic acid, indomethacin, piroxicam. esculetin, 3-(4,5-dimethylthiazol-2yl)-2,5-diphenyltetrazolium bromide (MTT), bovine serum albumin (BSA) 등 기타 실험에 사용한 시약은 Sigma Chemical Co. (St. Louis, MO)에서 구 입하였다. 세포 배양에 사용한 멸균된 1회용 플라스틱 용 기는 Corning (Corning, NY)에서 구입하여 사용하였다.

\section{2) 세포 배양}

세포는 $37^{\circ} \mathrm{C}$, 습윤한 $\mathrm{CO}_{2}$ incubator $\left(5 \% \mathrm{CO}_{2} / 95 \%\right.$ air)에 서 DMEM/F 12 를 사용하여 배양하였다. 실험에 사용할 세 포를 유지하기 위해 DMEM/F12 배지에 $10 \% \mathrm{FBS}$ 를 첨가 하고 미생물의 오염이나 증식을 억제하기 위해 항생제 (penicillin 100 units $/ \mathrm{ml}$, streptomycin $100 \mu \mathrm{g} / \mathrm{ml}$ )를 첨가한 배지를 사용하였다. 세포가 약 $80 \%$ 정도 dish를 덮으면 PBS으로 monolayer를 씻어내고 $0.25 \%$ trypsin- $2.65 \mathrm{mM}$ $\mathrm{EDTA}$ 를 처리하여 계대 배양하고 배지는 2 일마다 교환하 였다.

3) $\operatorname{COX}$ 또는 $\operatorname{LOX}$ 저해제의 농도에 따른 세포 증식 의 변화 측정

COX 또는 LOX 저해제의 농도를 달리 하였을 때 세포 의 증식에 미치는 영향을 알아보기 위해 세포를 $10 \% \mathrm{FBS}$ 가 포함된 배지로 희석하여 HT-29 세포는 $5 \times 10^{4}$ cells/well, Caco-2 세포는 $4 \times 10^{4}$ cells/well의 밀도가 되게 24 well plate 에 분주하였다. 24시간이 지난 후에 serum-free medium (SFM)으로 배지를 교환하고 24시간 동안 serum starvation 시켰다. SFM은 FBS가 없는 DMEM/F12에 transferrin $(5 \mu \mathrm{gd} /$ $\mathrm{ml})$, selenium $(5 \mathrm{~g} / \mathrm{ml})$, penicillin (100 units $/ \mathrm{ml})$, streptomycin $(100 \mu \mathrm{g} / \mathrm{ml})$ 을 첨가하여 만들었다. SFM에 포함되어 있는 리놀레산의 농도는 $0.15 \mu \mathrm{M}$ 이므로, 아라키돈산의 급원으 로 리놀레산을 $10 \mu \mathrm{M}$ 농도가 되게 첨가하여 실험 배지로 사용하였다. 이때 리놀레산은 지방산이 없는 BSA와 복합 체를 만들어 사용하였는데 형성된 linoleic acid-BSA 복합 체는 지방산과 $\mathrm{BSA}$ 의 몰비는 $4: 1$ 이었다. 실험 배지에 $\mathrm{COX}$ 저해제 또는 LOX 저해제를 각각 $0,25,50,100 \mu \mathrm{M}$ 의 농도로 달리하여 첨가해 주고 2 일, 4 일, 6 일 후에 MTT 분석(15) 방법으로 세포수를 측정하였다. MTT 분석 방법 은 미토콘드리아의 탈수소효소가 MTT를 환원시켜 푸른 색 물질인 formazan을 만든다는 원리를 기초로 한 것이다. 이 formazan을 isopropanol을 사용하여 용해시킨 후 570 $\mathrm{nm}$ 의 파장에서 흡광도를 측정하여 세포수를 측정하는 방 
법이다. 본 실험실에서 여러 번 예비 실험을 수행한 결과 MTT assay의 결과치는 직접 세포수를 측정한 측정치간의 직선적인 상관관계 $(\mathrm{r}=0.99)$ 를 나타낸다.

본 실험에 사용한 $\mathrm{COX}$ 저해제의 종류는 indomethacin, piroxicam이며, LOX 저해제는 esculetin이었다. 이 저해제 들은 $\mathrm{DMSO}$ 에 녹여 $100 \mathrm{mM}$ stock solution으로 만들어서 $-20^{\circ} \mathrm{C}$ 에 보관하여 사용하였으며 대조군을 포함한 모든 well의 $\mathrm{DMSO}$ 의 농도를 일정하게 유지시켰다.

\section{4) $\mathrm{PGE}_{2}$ 와 $\mathrm{LTB}_{4}$ 생성량 측정}

대장암 세포의 증식과 eicosanoid 생성과의 관련성을 시 험하기 위해서 세포들을 위에서 언급한 조건에서 배양하 여 serum-free conditioned media를 수집하였다. 배양액은 모은 즉시 glacial acetic acid를 첨가하여 $\mathrm{pH} 4.0$ 으로 조절 한 다음 에틸아세테이트 $(3: 1, \mathrm{v} / \mathrm{v})$ 를 이용하여 PG나 LT 를 추출하였다. 윗 부분의 유기층을 모아서 speed vac을 이용하여 건조시킨 다음 eicosanoid는 enzyme immunoassay kit (Cayman Chemicals Co, Ann Arbor, MI)를 이용하여 정 량 분석하였다.

5) $\mathrm{PGE}_{2}$ 와 $\mathrm{LTB}_{4}$ 의 농도에 따른 세포 증식의 변화 측정

Eicosanoid의 농도에 따른 세포 증식의 변화를 관찰하기 위해 Caco-2 세포를 $10 \% \mathrm{FBS}$ 가 포함된 배지로 희석하여 $4 \times 10^{4}$ cells/well 의 밀도로 24 well plate에 분주하였다. 24
시간이 지난 후 serum-starvation 시켰다. $\mathrm{SFM}$ 에 $\mathrm{PGE}_{2}$ 는 $0 \sim 100 \mu \mathrm{M}$ 의 농도로 첨가하고 $\mathrm{LTB}_{4}$ 는 $0 \sim 1 \mu \mathrm{M}$ 의 농도로 각각 첨가한 후 $24,48,72$ 시간에 MTT assay 방법으로 세 포수를 측정하였다.

6) 통계처리

모든 실험결과는 SAS 통계모델을 이용하여 분석하였 다. 각 실험군의 결과를 평균치와 표준오차로 나타내었고 각 실험군간의 비교는 ANOVA로 분석한 후 Duncan's multiple test를 이용하여 $a=0.05$ 에서 유의성을 검증하였다. $\mathrm{COX}$ 또는 $\mathrm{LOX}$ 저해제와 세포성장, $\mathrm{PGE}_{2}, \mathrm{LTB}_{4}$ 사이의 상관관계를 보기 위하여 Pearson 상관계수를 측정하였다.

\section{결 과}

1) $\operatorname{COX}$ 또는 $\operatorname{LOX}$ 저해제가 대장암 세포의 증식에 미치는 영향

암세포의 증식 억제와 관계가 있는 것으로 알려진 $\mathrm{COX}$ 또는 LOX 저해제가 암세포의 증식에 미치는 영향을 알아 보기 위해 세포내의 아라키돈산의 급원이 되는 리놀레산 을 $10 \mu \mathrm{M}$ 의 농도로 serum-free 배지에 첨가해주고 $\mathrm{COX}$ 저 해제(indomethacin, piroxicam) 또는 LOX 저해제(esculetin) 를 각각 $0,25,50,100 \mu \mathrm{M}$ 의 농도로 첨가하여 세포를 배 양한 후 MTT 방법을 이용하여 세포수를 측정하였다.
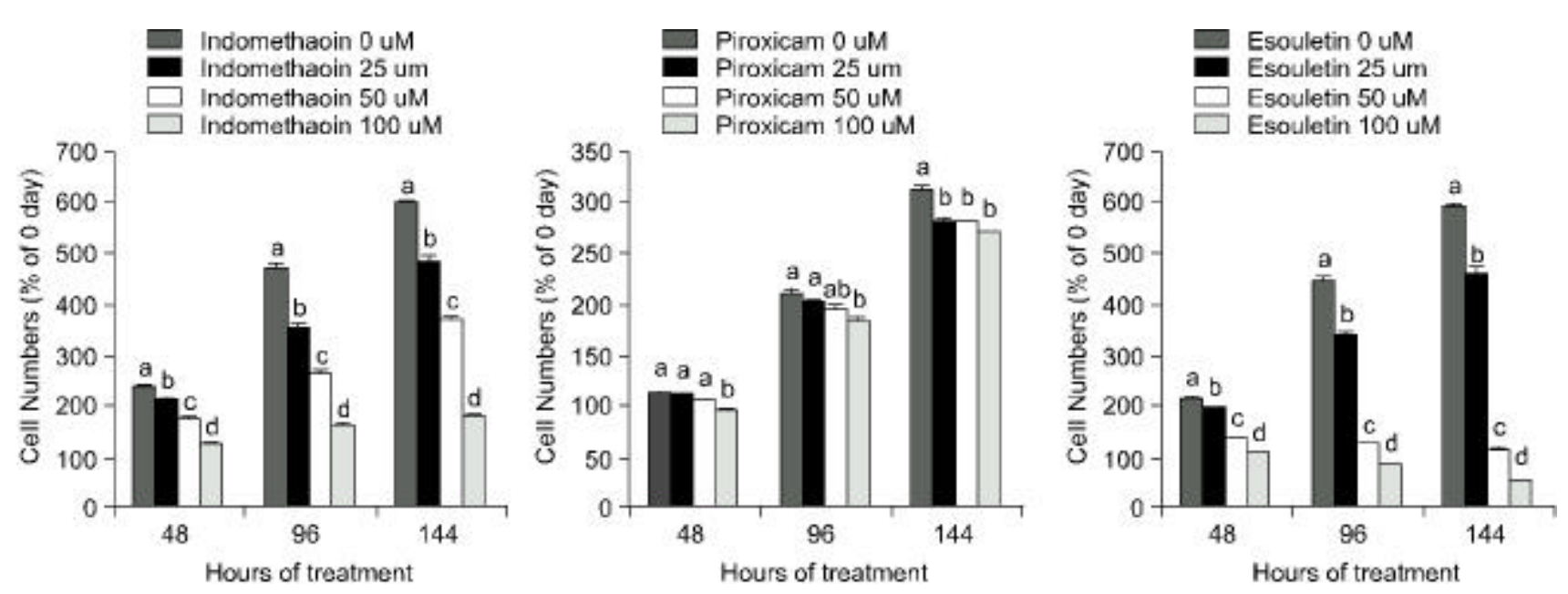

Fig. 1. Effect of COX and LOX inhibitors on the proliferation of Caco-2 cells in the presence of 10 $\mu$ M LA. Cells were plated in 24-well plates in DMEM/F 12 supplemented with $10 \%$ fetal bovine serum. One day later, the monolayers were serum-starved with serum-free DMEM/F 12 supplemented with $5 \mu \mathrm{g} / \mathrm{ml}$ transferrin and $5 \mathrm{ng} / \mathrm{ml}$ Se for 24 hours. After serum starvation (0 day), cells were incubated in serum-free medium containing 10 $\mu \mathrm{M}$ LA with or without various concentrations of COX or LOX inhibitors. Cell numbers were estimated by the MTT assay. The data were expressed as a percentage of day 0 value. Each bar represents the mean \pm SEM $(n=6)$. ANOVA, followed Duncan's multiple range test at each time point was used to determine significant differences among the treatment groups. Comparisons between groups that yielded significant differences $(p<0.05)$ are indicated by different letters above each bar. Data for groups that share the same letter are not significantly different. 
Caco-2 세포는 indomethacin을 첨가한 결과 48시간 후부터 농도에 따른 유의적인 세포 증식 감소를 관찰할 수 있었 다. 그러나 piroxicam은 농도에 따른 세포 증식 억제 효과 가 첨가 후 144 시간이 지났을 경우에만 나타났고 세포 증 식 감소 정도도 indomethacin보다 훨씬 적었다(Fig. 1). LOX 저해제인 esculetin을 같은 농도로 첨가하였을때 $\mathrm{COX}$ 저 해제보다 세포 증식 감소 효과가 컸다(Fig. 1).

Fig. 2에는 리놀레산을 $10 \mu \mathrm{M}$ 의 농도로 첨가해 준 상태 에서 HT-29 세포 증식에 대한 $\mathrm{COX}$ 또는 LOX 저해제의 효과를 나타내었다. HT-29 세포는 Caco-2와는 달리 indomethacin $50 \mu \mathrm{M}$ 이상에서만 세포 증식 감소 효과가 나타 났으며, 또 다른 $\mathrm{COX}$ 저해제인 piroxicam은 $0 \sim 100 \mu \mathrm{M}$ 의 농도로 첨가해 주어도 세포증식 억제효과가 거의 없었다. LOX 저해제인 esculetin은 $100 \mu \mathrm{M}$ 에서만 유의적으로 세포 증식을 감소시켰다.

Fig. 3에는 Fig. 1과 동일한 조건에서 아라키돈산의 급원 인 리놀레산을 첨가하지 않았을 경우, 즉 배지에 포함된 리놀레산의 농도가 $0.15 \mu \mathrm{M}$ 일 때, $\mathrm{COX}$ 또는 $\mathrm{LOX}$ 저해제 가 Caco-2 세포주의 증식에 미친 영향을 나타내었다. 그 결과 Caco-2 세포는 리놀레산을 첨가해 주었을 때와 같이 $\mathrm{COX}$ 와 $\mathrm{LOX}$ 저해제에 의해 세포 증식이 억제되는 것으로 나타났다. 이것은 HT-29 세포주에서도 마찬가지였다(결과 생략). 즉 $10 \mu \mathrm{M}$ 리놀레산의 첨가여부는 $\mathrm{COX}$ 와 $\mathrm{LOX}$ 저 해제의 세포증식 억제 작용에 영향을 미치지 않았다.
2) $\mathrm{COX}$ 또는 $\mathrm{LOX}$ 저해제가 대장암 세포주에서 $\mathrm{PGE}_{2}$ 와 $\mathrm{LTB}_{4}$ 생성에 미치는 영향

리놀레산을 $10 \mu \mathrm{M}$ 첨가한 후 $\mathrm{COX}$ 저해제 indomethacin 과 piroxicam, 또는 LOX 저해제 esculetin을 첨가하여 doseresponse 실험에서 모은 serum-free conditioned medium을 이용하여 $\mathrm{PGE}_{2}$ 와 $\mathrm{LTB}_{4}$ 농도를 측정하였다.

Caco-2 세포주에서 indomethacin의 농도에 관계없이 모 든 농도에서 $\mathrm{PGE}_{2}$ 의 농도가 현저히 감소하였다. Piroxicam 은 세포증식에 미치는 영향은 적었던 반면 $\mathrm{PGE}_{2}$ 의 농도 는 유의적으로 감소시키는 것으로 나타났다. LOX 저해제 인 esculetin에 의해서도 $\mathrm{PGE}_{2}$ 의 농도가 감소하였으나 $\mathrm{COX}$ 저해제에 의한 것보다 농도에 따른 $\mathrm{PGE}_{2}$ 감소폭이 적었 다. $\mathrm{LTB}_{4}$ 농도는 esculetin을 $100 \mu \mathrm{M}$ 로 첨가해 주었을 때 만 유의적으로 감소하였다. Indomethacin은 dose-dependent 하게 $\mathrm{LTB}_{4}$ 농도를 증가시켰으며 piroxicam도 이보다는 적 으나 첨가 농도가 증가할수록 $\mathrm{LTB}_{4}$ 의 농도를 증가시키는 경향이었다(Fig. 4).

HT-29 세포에서는 indomethacin 농도가 증가할수록 $\mathrm{PGE}_{2}$ 의 농도는 감소하였고 piroxicam의 경우에는 $50 \mu \mathrm{M}$ 에서 그 효과가 나타났다. 세포 증식 감소 효과가 컸던 indomethacin이 piroxicam보다 $\mathrm{PGE}_{2}$ 를 더 많이 감소시켰다. $\mathrm{LOX}$ 저해제인 esculetin에 대해서는 Caco-2 세포주에서와는 달 리 esculetin의 첨가농도와 $\mathrm{PGE}_{2}$ 의 농도 사이에 dose-depen-
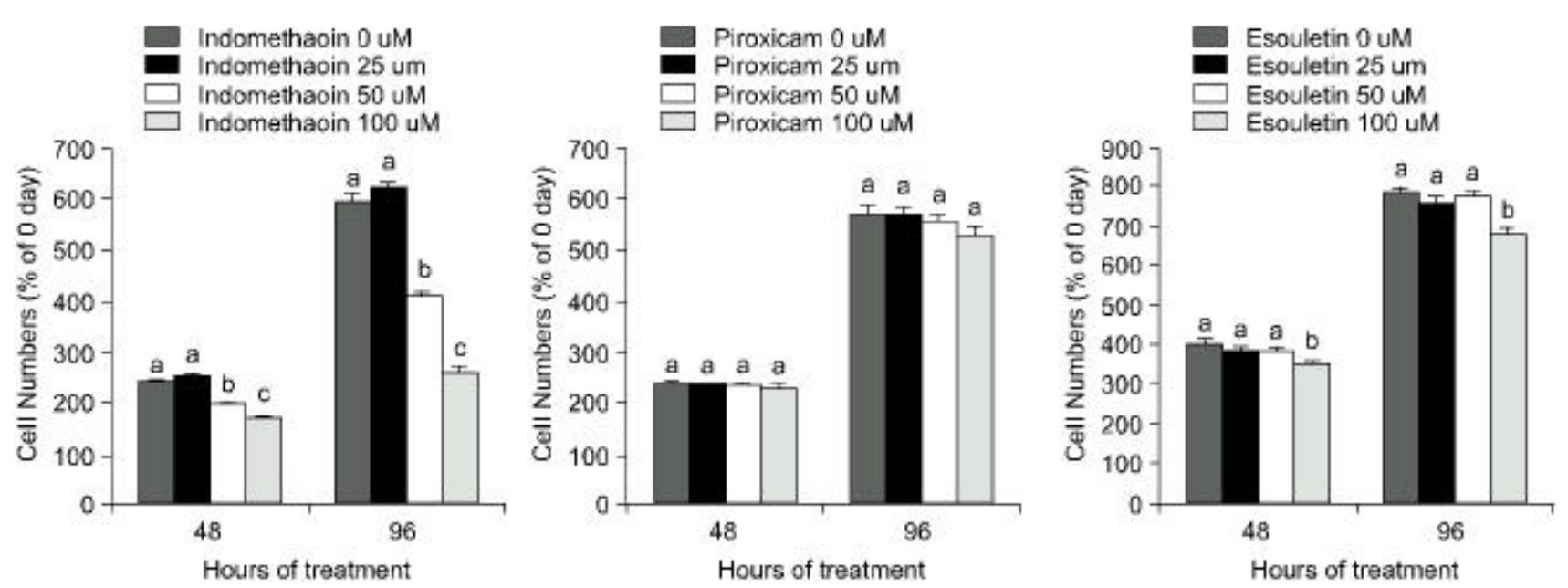

Fig. 2. Effect of COX or LOX inhibitor on the proliferation of HT-29 cells in the presence of 10 $\mu$ M LA. Cells were plated and cultured as described in Fig. 1. After serum starvation ( 0 day), cells were incubated in serum-free medium containing $10 \mu \mathrm{M}$ LA with or without various concentrations of COX or LOX inhibitors. Cell numbers were estimated by the MTT assay. The data were expressed as a percentage of day 0 value. Each bar represents the mean \pm SEM $(n=6)$. ANOVA, followed Duncan's multiple range test at each time point was used to determine significant differences among the treatment groups. Comparisons between groups that yielded significant differences $(\mathrm{p}<0.05)$ are indicated by different letters above each bar. Data for groups that share the same letter are not significantly different. 

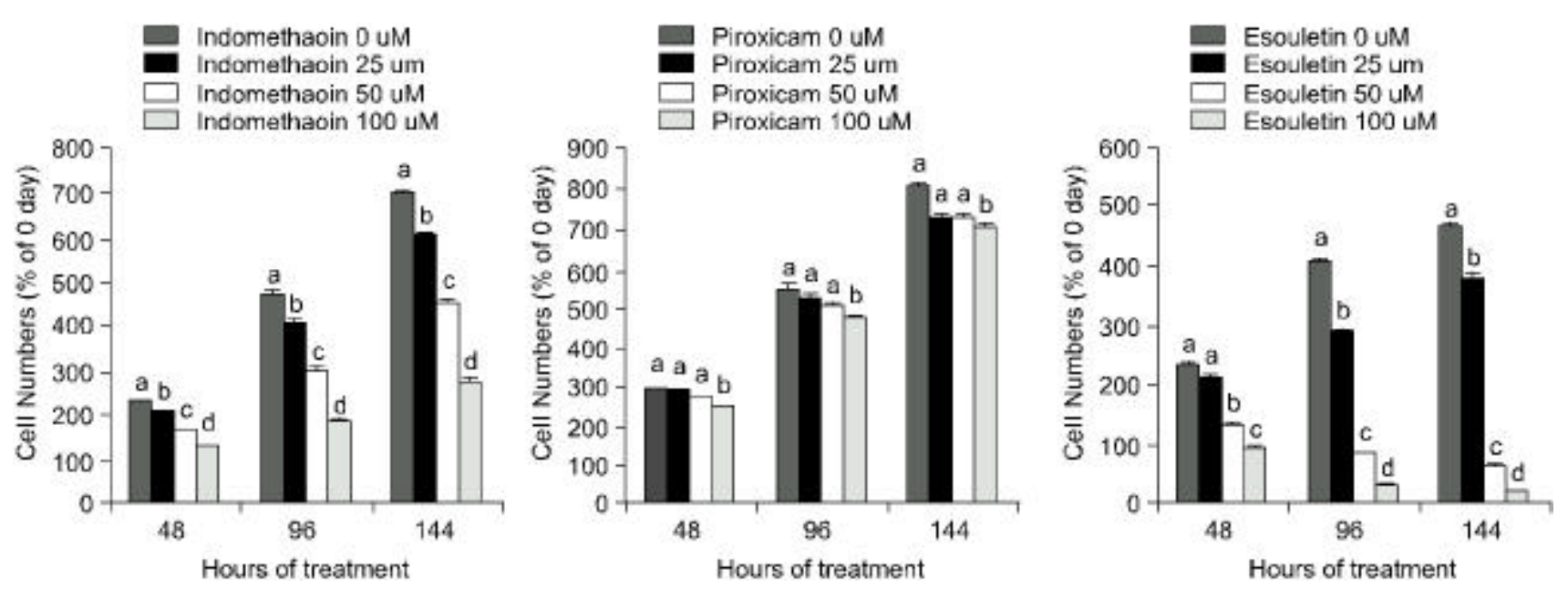

Fig. 3. Effect of cyclooxygenase (COX) and lipoxygenase (LOX) inhibitors on the proliferation of Caco- 2 cells in the presence of $0.15 \mu \mathrm{M}$ LA. Cells were plated and serum- starved as described in Fig. 1. After serum starvation, cells were incubated in serum-free medium with or without various concentrations of COX or LOX inhibitors. Cell numbers were estimated by the MTT assay. The data were expressed as a percentage of day 0 value. Each bar represents the mean \pm SEM $(n=6)$. ANOVA, followed Duncan's multiple range test at each time point was used to determine significant differences among the treatment groups. Comparisons between groups that yielded significant differences $(\mathrm{p}<0.05)$ are indicated by different letters above each bar. Data for groups that share the same letter are not significantly different.
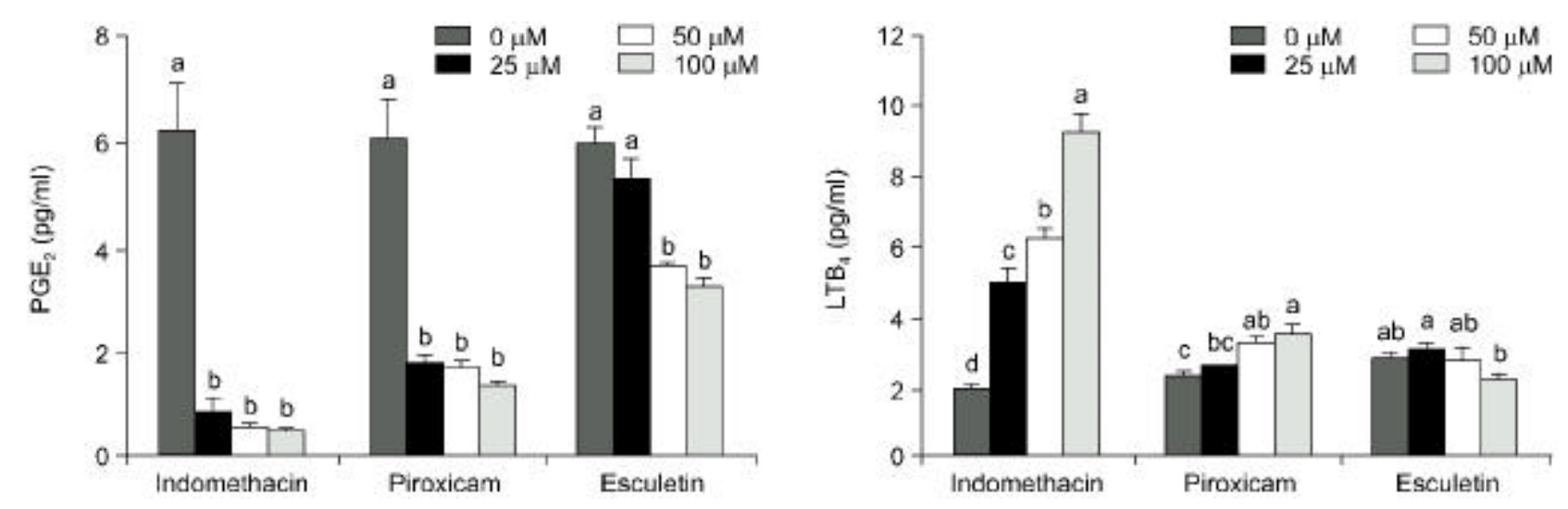

Fig. 4. Effect of COX and LOX inhibitors on $\mathrm{PGE}_{2}$ and $\mathrm{LTB}_{4}$ concentrations in the conditioned medium by Caco-2 cells in the presence of $10 \mu \mathrm{M}$ LA. Cells were plated and cultured as described in Fig. 1. After serum starvation, cells were incubated in serum-free medium containing 10 $\mathrm{M}$ LA with or without various concentrations COX or LOX inhibitors. Conditioned media were acidified with glacial acetic acid, and $\mathrm{PGE}_{2}$ or $\mathrm{LTB}_{4}$ was extracted with ethyl acetate and estimated by a competitive enzyme immunoassay. ANOVA, followed Duncan's multiple range test with each inhibitor was used to determine significant differences among the treatment groups. Comparisons between groups that yielded significant differences $(p<0.05)$ are indicated by different letters above each bar. Data for groups that share the same letter are not significantly different.

dent한 경향을 볼 수 없었다. $\mathrm{LTB}_{4}$ 농도는 esculetin의 농도 를 $100 \mu \mathrm{M}$ 로 첨가했을 때 감소하였다. Indomethacin은 50 $\mu \mathrm{M}$ 농도에서 $\mathrm{LTB}_{4}$ 농도를 증가시켰고 piroxicam의 경우 $25 \mu \mathrm{M}$ 의 농도에서 적지만 $\mathrm{LTB}_{4}$ 의 농도 증가를 가져왔으 며 농도가 그 이상 증가되어도 $\mathrm{LTB}_{4}$ 의 생성은 증가되지 않았다(Fig. 5). 배지에 포함된 리놀레산의 농도가 $0.15 \mu \mathrm{M}$ 일 때 Caco-2 cell에 의해서 생성되는 $\mathrm{PGE}_{2}$ 의 양이(Fig. 6)
$10 \mu \mathrm{M}$ 와 비교해서 전반적으로 낮았다(Fig. 4). 그러나 낮 은 농도의 리놀레산이 포함된 배양액에서 이 NSAID들이 Caco-2 cell의 $\mathrm{PGE}_{2}$ 나 $\mathrm{LTB}_{4}$ 생성에 미치는 영향은 리놀레 산의 농도가 $10 \mu \mathrm{M}$ 일 때와 비슷하였다(Fig. 6).

\section{3) 대장암 세포 증식과 $\mathrm{PGE}_{2}$ 와 $\mathrm{LTB}_{4}$ 사이의 관계}

Caco-2 세포주에서 indomethacin, piroxicam, esculetin 첨 

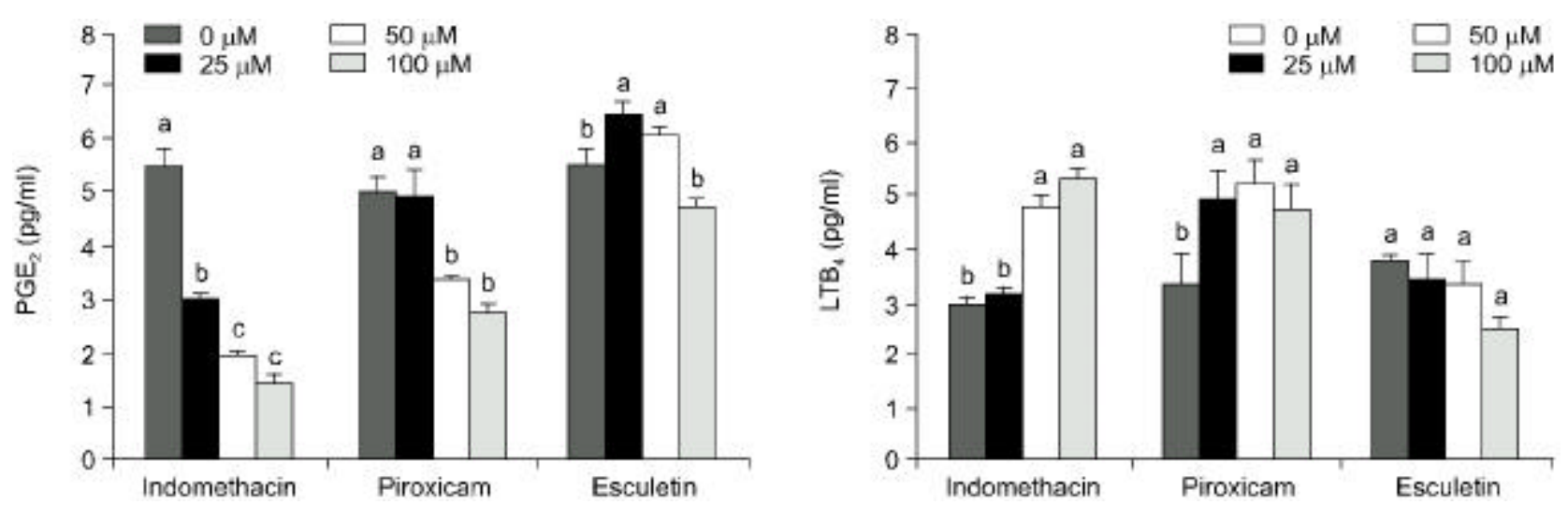

Fig. 5. Effect of COX and LOX inhibitors on $\mathrm{PGE}_{2}$ and $\mathrm{LTB}_{4}$ concentrations in the conditioned medium by HT-29 cells in the presence of $10 \mu \mathrm{M}$ LA. Cells were plated and cultured as described in Fig. 1. After serum starvation, cells were incubated in serum-free medium containing 10 $\mu$ M LA with or without various concentrations COX or LOX inhibitors. Conditioned media were acidified with glacial acetic acid, and $\mathrm{PGE}_{2}$ and $\mathrm{LTB}_{4}$ was extracted with ethyl acetate and estimated by a competitive enzyme immunoassay. ANOVA, followed Duncan's multiple range test with each inhibitor was used to determine significant differences among the treatment groups. Comparisons between groups that yielded significant differences $(p<0.05)$ are indicated by different letters above each bar. Data for groups that share the same letter are not significantly different.
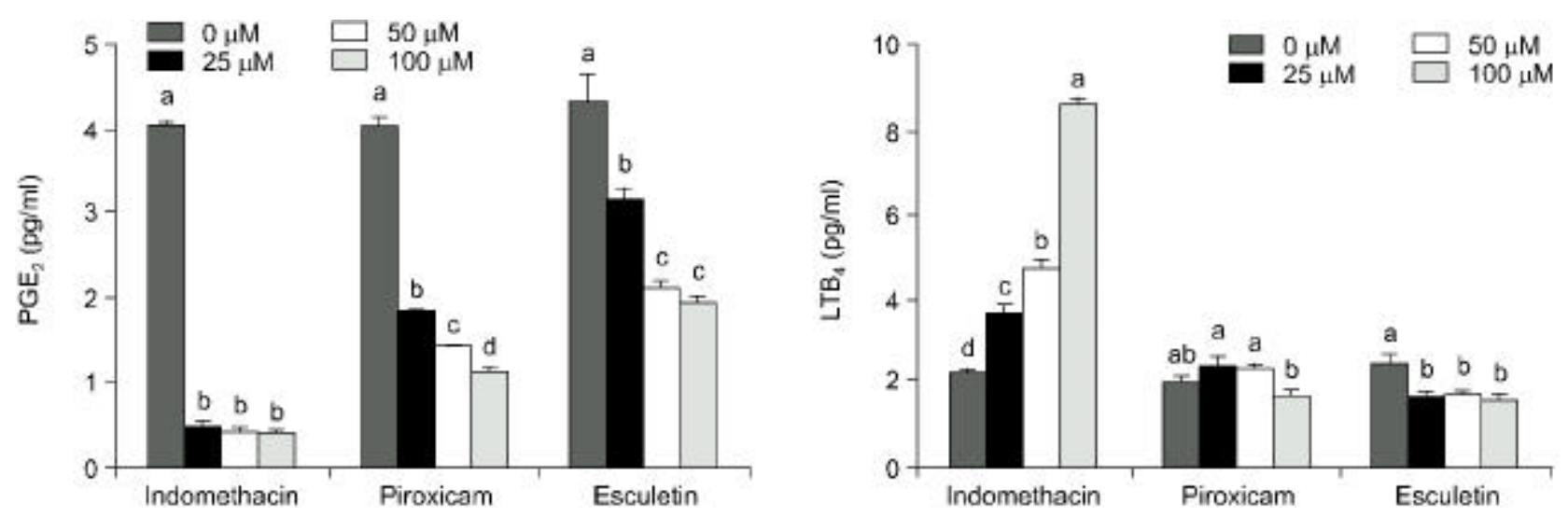

Fig. 6. Effect of COX and LOX inhibitors on $\mathrm{PGE}_{2}$ and $\mathrm{LTB}_{4}$ concentrations in the conditioned medium by Caco- 2 cells in the presence of $0.15 \mu \mathrm{M}$ LA. Cells were plated and cultured as described in Fig. 3. Conditioned media were collected and acidified with glacial acetic acid. $\mathrm{PGE}_{2}$ and $\mathrm{LTB}_{4}$ was extracted with ethyl acetate and estimated by a competitive enzyme immunoassay. ANOVA, followed Duncan's multiple range test with each inhibitor was used to determine significant differences among the treatment groups. Comparisons between groups that yielded significant differences $(\mathrm{p}<0.05)$ are indicated by different letters above each bar. Data for groups that share the same letter are not significantly different.

가에 따른 세포증식과 $\mathrm{PGE}_{2}$ 및 $\mathrm{LTB}_{4}$ 농도와의 상관관계 를 Table 1에 나타내었다. Caco-2 세포에서 세포 증식은 indomethacin, piroxicam, esculetin 첨가 농도와 유의적인 음 의 상관관계를 보였다 $(\mathrm{p}<0.001)$. Indomethacin 첨가시 세 포 증식은 $\mathrm{PGE}_{2}$ 와 유의적인 양의 상관관계 $(\mathrm{p}<0.001)$ 를 보였고, $\mathrm{LTB}_{4}$ 와는 유의적인 음의 상관관계 $(\mathrm{p}<0.001)$ 를 보 였다. Piroxicam 첨가시 세포증식은 $\mathrm{PGE}_{2}$ 와 $\mathrm{LTB}_{4}$ 둘 다 $\mathrm{p}$ $<0.01$ 수준에서 양의 상관관계를 보였다. Esculetin 첨가 시 세포증식과 $\mathrm{PGE}_{2}$ 와 $\mathrm{LTB}_{4}$ 의 농도 사이에는 각각 $\mathrm{p}<$
$0.001, \mathrm{p}<0.01$ 수준에서 양의 상관관계를 보였다. Indomethacin 첨가시 $\mathrm{PGE}_{2}$ 와 $\mathrm{LTB}_{4}$ 사이에는 음의 상관관계 $(\mathrm{p}<$ $0.001)$ 가 나타났다. Piroxicam을 첨가해 준 경우는 $\mathrm{PGE}_{2}$ 와 $\mathrm{LTB}_{4}$ 사이에 유의적인 상관관계가 없었으며, esculetin을 첨가해준 경우에는 $\mathrm{PGE}_{2}$ 와 $\mathrm{LTB}_{4}$ 사이에 유의적인 양의 상관관계 $(\mathrm{p}<0.001)$ 를 보였다.

Table 2에는 HT-29 세포주에서 indomethacin, piroxicam, esculetin 첨가에 따른 세포증식과 $\mathrm{PGE}_{2}$ 및 $\mathrm{LTB}_{4}$ 농도와의 상관관계를 제시하였다. HT-29 세포에서도 
410 Cancer Research and Treatment 2001;33(5)

Table 1. Correlation between the concentrations of individual COX and LOX inhibitors, cell growth, $\mathrm{PGE}_{2}$, and $\mathrm{LTB}_{4}$ concentrations in Caco-2 cells by Pearson correlation analysis

\begin{tabular}{|c|c|c|c|c|}
\hline & Indomethacin & Cell growth & $\mathrm{PGE}_{2}$ & $\mathrm{LTB}_{4}$ \\
\hline Indomethacin & 1.0000 & & & \\
\hline Cell growth & $-0.9795^{\ddagger}$ & 1.0000 & & \\
\hline $\mathrm{PGE}_{2}$ & $-0.6980^{\ddagger}$ & $0.6941^{\ddagger}$ & 1.0000 & \\
\hline \multirow[t]{2}{*}{$\mathrm{LTB}_{4}$} & $0.9872^{\ddagger}$ & $-0.9480^{\ddagger}$ & $-0.6423^{\ddagger}$ & 1.0000 \\
\hline & Piroxicam & Cell growth & $\mathrm{PGE}_{2}$ & $\mathrm{LTB}_{4}$ \\
\hline Piroxicam & 1.0000 & & & \\
\hline Cell growth & $-0.7858^{\ddagger}$ & 1.0000 & & \\
\hline $\mathrm{PGE}_{2}$ & $-0.8213^{\ddagger}$ & $0.5418^{\dagger}$ & 1.0000 & \\
\hline \multirow[t]{2}{*}{$\mathrm{LTB}_{4}$} & $-0.5655^{\ddagger}$ & $0.5359^{\dagger}$ & 0.1164 & 1.0000 \\
\hline & Esculetin & Cell growth & $\mathrm{PGE}_{2}$ & $\mathrm{LTB}_{4}$ \\
\hline Esculetin & 1.0000 & & & \\
\hline Cell growth & $-0.9534^{\ddagger}$ & 1.0000 & & \\
\hline $\mathrm{PGE}_{2}$ & $-0.8610^{\ddagger}$ & $0.8830^{\ddagger}$ & 1.0000 & \\
\hline $\mathrm{LTB}_{4}$ & $-0.6313^{\ddagger}$ & $0.5303^{\dagger}$ & $0.6804^{\ddagger}$ & 1.0000 \\
\hline
\end{tabular}

${ }^{*} \mathrm{p}<0.05,{ }^{\dagger} \mathrm{p}<0.01,{ }^{\ddagger} \mathrm{p}<0.001$

Table 2. Correlation between the concentration of individual COX and LOX inhibitors, cell growth, $\mathrm{PGE}_{2}$, and $\mathrm{LTB}_{4}$ concentrations in HT-29 cells by Pearson correlation analysis

\begin{tabular}{lccc}
\hline & Indomethacin & Cell growth & PGE $_{2}$ \\
\hline Indomethacin & 1.0000 & & \\
Cell growth & $-0.8919^{\ddagger}$ & 1.0000 & 1.0000 \\
PGE $_{2}$ & $-0.8733^{\ddagger}$ & $0.7385^{\ddagger}$ & $-0.8301^{\ddagger}$ \\
LTB $_{4}$ & $0.9061^{\ddagger}$ & $-0.9453^{\ddagger}$ & PGE $_{2}$ \\
\hline & Piroxicam & Cell growth & 1.0000 \\
\hline Piroxicam & 1.0000 & & 1.0000 \\
Cell growth & $-0.74431^{*}$ & 1.0000 & $-0.5438^{\dagger}$ \\
PGE $_{2}$ & $-0.8800^{\ddagger}$ & 0.3254 & LTB $_{4}$ \\
LTB $_{4}$ & $0.4225^{*}$ & 0.1004 & PGE $_{2}$ \\
\hline & Esculetin & Cell growth & 1.0000 \\
\hline Esculetin & 1.0000 & & 1.0000 \\
Cell growth & $-0.8213^{\ddagger}$ & 1.0000 & $0.4320^{*}$ \\
PGE & $-0.4550^{*}$ & $0.4741^{*}$ & LTB $_{4}$ \\
LTB $_{4}$ & $-0.7151^{\ddagger}$ & $0.5563^{\dagger}$ & \\
\hline
\end{tabular}

${ }^{*} \mathrm{p}<0.05,{ }^{\dagger} \mathrm{p}<0.01,{ }^{\ddagger} \mathrm{p}<0.001$ 
A

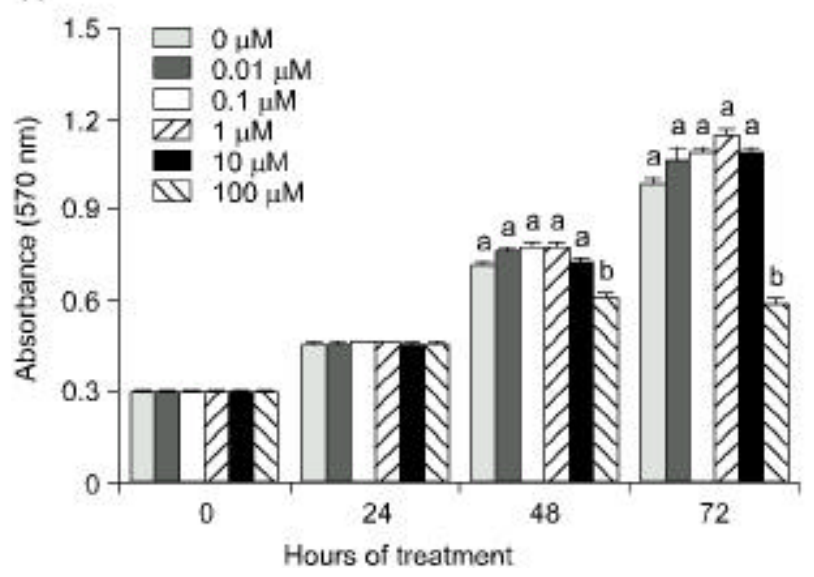

B

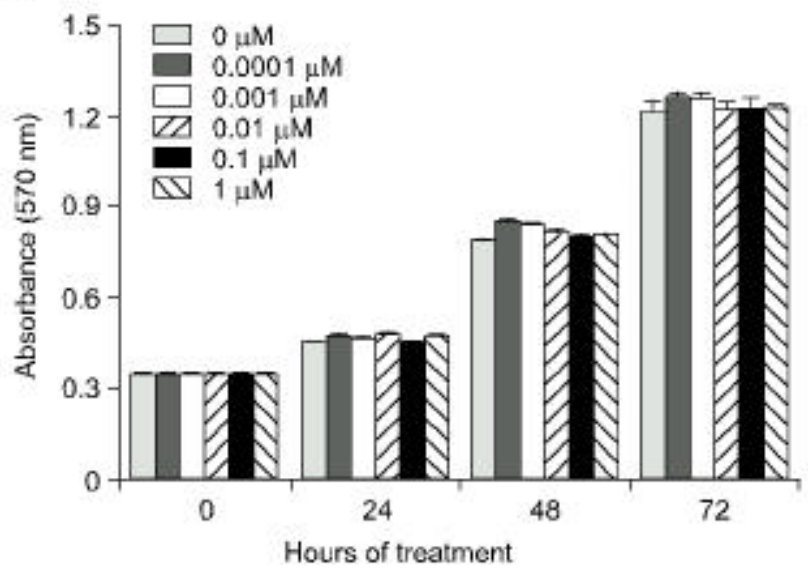

Fig. 7. Effect of exogenous $\mathrm{PGE}_{2}(\mathrm{~A})$ and $\mathrm{LTB}_{4}$ (B) on the proliferation of Caco-2 cells. Cells were plated and serum-starved described in Fig. 1. After serum starvation, cells were incubated in the absence or presence of various concentrations of exogenous PGE $_{2}$ or $\mathrm{LTB}_{4}$. Cell numbers were estimated by the MTT assay. Each bar represents the mean \pm SEM $(n=8)$. Comparisons between different concentrations of individual eicosanoids that yielded significant differences $(\mathrm{p}<0.05)$ are indicated by different letters above each bar.

indomethacin과 세포증식, $\mathrm{PGE}_{2}, \mathrm{LTB}_{4}$ 와의 상관관계는 Caco-2 세포에서와 같았다. 그러나 piroxicam은 $\mathrm{Caco}-2$ 세포에서와는 달리 piroxicam 농도와 $\mathrm{LTB}_{4}$ 농도 사이에 양의 상관관계 $(\mathrm{p}<0.05)$ 를 보였으며 $\mathrm{PGE}_{2}$ 와 $\mathrm{LTB}_{4}$ 와 세 포증식 간에 유의적인 상관관계가 없었다. Esculetin은 이 세포에서도 Ccco-2 세포에서와 마찬가지로 세포증 식, $\mathrm{PGE}_{2}, \mathrm{LTB}_{4}$ 농도 사이에 음의 상관관계(각각 $\mathrm{p}<$ $0.001, \mathrm{p}<0.05, \mathrm{p}<0.001)$ 를 보였다.

위의 결과로 볼 때 $\mathrm{COX}$ 저해제인 indomethacin과 piroxicam, 그리고 LOX 저해제인 esculetin은 모두 세포 증식을 억제하는 작용이 있으며, $\mathrm{PGE}_{2}$ 와 $\mathrm{LTB}_{4}$ 는 세포 증식과 유의적인 상관관계를 가지나, 이것은 암세포의 종류에 따라 그 효과가 다르며 $\mathrm{COX}$ 저해제의 종류에 따라서도 다른 영향을 나타내는 것을 알 수 있다.

4) $\mathrm{PGE}_{2}$ 와 $\mathrm{LTB}_{4}$ 가 대장 암세포 증식에 미치는 영향

Eicosanoid의 농도가 증가했을 때 세포증식에 미치는 영 향을 관찰하고자 외인성 eicosanoid를 Caco-2 세포에 첨가 해 주었을 때의 세포증식에 미친 영향을 살펴보았다. PGE2 를 $0 \sim 100 \mu \mathrm{M}$ 의 농도로 첨가한 후 $24,48,72$ 시간이 지난 후에 세포수를 측정한 결과 $100 \mu \mathrm{M}$ 의 농도에서 세포 증 식이 감소한 외에는 $\mathrm{PGE}_{2}$ 를 첨가해줘도 세포 증식에는 영향을 미치지 않았다. 또한 $0 \sim 1 \mu \mathrm{M}$ 농도의 $\mathrm{LTB}_{4}$ 를 첨 가해 준 경우도 $\mathrm{PGE}_{2}$ 와 마찬가지로 세포증식에 영향을 미치지 않았다(Fig. 7).

\section{고 찰}

역학조사와 동물 실험에서 NSAIDs는 대장암 위험률을 감소시키는 것으로 나타났으나(4 6) NSAIDs가 어떤 기전 을 통해 대장암에 작용하는지는 아직 잘 알려진 바가 없다. NSAIDs가 COX 또는 LOX의 활성을 저해하는 기능이 있음 이 알려져, NSAIDs가 이들 효소에 영항을 미쳐 eicosanoid 의 생성량을 변화시킴으로서 암세포의 작용을 억제할 것이 라는 가설이 대두되었다. Eicosanoid는 상피세포 증식을 촉 진 또는 억제하는 능력을 갖고 있으며, 일부 암세포 주에서 성장 조절 기능이 있음이 밝혀졌다. 대장암 환자에서 대장 점막의 $\mathrm{PGE}_{2}$ 농도가 정상인보다 높은데, 이 환자에게 하루 에 $7.5 \mathrm{mg}$ 의 piroxicam 투여시 생존기간이 연장되었고 대장 점막의 $\mathrm{PGE}_{2}$ 농도가 유의적으로 감소되었다(16). 또한 여러 in vitro 실험 결과를 보면 $\mathrm{COX}$, 특히 COX-2 발현과 대장 암 사이에 양의 상관관계가 있음이 밝혀졌다. $\mathrm{COX}$ 와 LOX 저해제에 의한 암세포 증식 억제 작용은 대장암 세포주 뿐 만 아니라 인간 유래 유방암 세포주(17), 췌장암 세포주(18) 에서도 보고되었다. 인간 유래 소화기계암 세포주(AGS)는 아라키돈산이 5-LOX 경로를 통해 우선적으로 대사되게 함 으로써 이로 인해 성장촉진 물질이 생성되므로 이 과정을 막을 수 있는 물질은 일부 소화기계 암의 치료제로 사용될 수 있을 것으로 기대된다. LOX 저해제인 nordihydroguairetic acid (NDGA)는 폐암 세포주인 NCI-H1264에서 5-LOX를 저해하였으며 세포증식을 억제하였다. 즉 LOX 저해제가 폐 암 증식과 발암물질 발현을 막을 수 있음을 의미한다(19). 
또한 NDGA가 췌장암 세포주에서 apoptosis를 유발하는 것 이 밝혀져 LOX 효소를 차단하면 인간의 췌장암 치료에 도 움을 줄 수 있을 것으로 보고되었다(18).

본 연구에서는 $\mathrm{COX}$ 와 LOX의 일반적인 저해제들을 사용 하여 이들이 세포증식과 $\mathrm{PGE}_{2}$ 또는 $\mathrm{LTB}_{4}$ 에 미치는 영향을 살펴보고, 이들 사이의 상관관계를 구하였다. 본 연구에서 사용한 COX 저해제-indomethacin, piroxicam중 indomethacin 의 세포증식 억제효과가 컸다. Piroxicam은 $100 \mu \mathrm{M}$ 농도에 서 Caco-2 세포주에서는 세포증식 억제효과가 적게 나타났 고 HT-29 세포주에서는 세포증식 억제효과를 보이지 않았 다. $\mathrm{LOX}$ 저해제인 esculetin을 $\mathrm{COX}$ 저해제와 같은 농도로 첨가 시 그 효과가 $\mathrm{COX}$ 저해제보다 휠씬 컸다. 이러한 LOX와 COX의 저해제의 효과는 Noguchi등(20)의 연구에서 도 마찬가지여서, 그는 인간 유래 유방암 세포주(MDA-MB231)에서 piroxicam과 esculetin으로 LOX와 COX의 작용을 비교한 결과 이 둘의 산물에 의해서 세포의 성장이 영향받 는데, 그 중 $\mathrm{LOX}$ 의 작용을 저해했을 때 세포 성장이 더욱 억제된다고 하였다.

Hofmanova등(21)은 인간 유방암 세포주인 HS578T와 monoblastoid U937 세포주에서 연구 결과, piroxicam은 $\mathrm{COX}$ 경로의 저해제이나 세포 증식에 유의적인 영향을 미치지 않았다고 보고하였다. 이것은 본 연구에서도 나 타난 결과로서 piroxicam은 대장암 세포주의 증식억제 효과를 나타내지 않았다. 그런데 piroxicam 첨가에 의 해 $\mathrm{PGE}_{2}$ 의 농도는 유의적으로 감소하여 $\mathrm{PGE}_{2}$ 의 농도 감소가 전적으로 암세포의 증식 억제를 유발하는 원인 이 아님을 알 수 있었다. 그리고 본 연구의 Table 1,2 에 의하면 $\mathrm{COX}$ 또는 $\mathrm{LOX}$ 저해제와 세포증식과의 상 관관계에 비해 $\mathrm{PGE}_{2}$ 또는 $\mathrm{LTB}_{4}$ 생성량과 세포성장과 의 상관관계가 적어 $\mathrm{COX}$ 또는 $\mathrm{LOX}$ 저해에 의한 eicosanoid 생성량의 변화가 암세포증식억제에 전적인 영 향을 미친 것은 아니라는 것을 알 수 있다. 또한 $\mathrm{PGE}_{2}$ 와 $\mathrm{LTB}_{4}$ 를 직접 배지에 첨가해 준 경우에도 $100 \mu \mathrm{M}$ 의 $\mathrm{PGE}_{2}$ 첨가 시에만 세포수가 감소하였을 뿐 세포수에 변화가 없는 것(Fig. 7)으로 보아 eicosanoid의 농도 증 가가 암세포의 증식에 직접적으로 영향을 미치지 않는 것으로 보인다. Parker등(22)은 HT-29 세포에서 $\mathrm{PGE}_{2}$ 를 첨가하여 세포증식의 변화를 본 결과 $10 \mu \mathrm{M}$ 이상 첨가 시에 세포수가 감소하기 시작하여 $100 \mu \mathrm{M}$ 첨가 시 유 의적인 세포감소를 나타냈음을 보고하여 본 연구에서 와 같은 경향을 나타냈다. 또 본 실험에서 eicosanoid의 전구체라고 할 수 있는 리놀레산의 농도 변화가 NSAID 의 세포 증식억제 작용에 영향을 미치지 않았고 이 물 질들에 의한 eicosanoid 생성변화에도 별다른 영향을 미
치지 않았다.

즉 $\mathrm{COX}$ 또는 $\mathrm{LOX}$ 저해제에 의한 암세포증식 억제 작용은 eicosanoid 생성량 외에 다른 기전이 존재할 가 능성이 있음을 의미한다. 실제로 indomethacin의 경우 caspase-3에 의존적인 기전을 통해서 apoptosis를 유발시 키며(23), in vivo에서 암세포의 telomerase 활성에 영향 을 미침으로써 암세포 증식을 억제하고(24), COX-2 저 해제는 $\mathrm{PG}$ 합성에 작용하는 것과는 상관없이 세포 주 기 진행을 방해함으로써 암 억제작용을 한다고 보고되 었다(25).

또한 본 연구에서 암세포 증식 억제 작용은 세포주 의 종류와 $\mathrm{COX}$ 또는 $\mathrm{LOX}$ 저해제의 종류에 따라 차이 가 있는 것으로 나타났다. Hofmanova(21)도 esculetin은 LOX 저해제로서 세포증식을 억제하는 효과가 있는데, 이것의 작용은 세포주의 종류와 처치 시간에 대한 세 포주기의 변화에 의해서 영향을 받는다고 하여 $\mathrm{COX}$ 와 LOX 저해제에 의한 암세포증식억제와 eicosanoid 생성 량에 미치는 영향은 저해제의 종류와 암세포의 종류에 따라 차이가 있음을 보고했다.

이런 결과로 볼 때 대장암 세포는 COX와 LOX 저해 제에 의해 증식이 억제되는데, 이것은 $\mathrm{PGE}_{2}$ 와 $\mathrm{LTB}_{4}$ 농 도 둘 다에 독립적으로 관련있으나, 이들이 암세포 증 식에 전적으로 영향을 미치는 것은 아니며, 이런 영향 은 세포의 종류와 저해제의 종류에 따라 다르게 나타 나는 것으로 볼 수 있다.

\section{결 론}

본 연구에서 사용한 Caco-2와 HT-29 등 대장암 세포 는 $\mathrm{COX}$ 또는 $\mathrm{LOX}$ 저해제에 의해 그 증식이 억제되었 다. $\mathrm{COX}$ 또는 $\mathrm{LOX}$ 저해제는 $\mathrm{PGE}_{2}$ 생성량을 감소 시 켰으며 $\mathrm{LTB}_{4}$ 의 생성량을 증가 또는 감소 시켰다. 이것 은 둘 다 암세포증식 억제와 상관관계가 있어 $\mathrm{COX}$ 또 는 LOX 저해제에 의해 eicosanoid의 생성량이 변화하 여 암세포증식을 억제할 것이라는 가설에 합치하는 소 견을 보여주었다. 그러나 세포증식과 $\mathrm{COX}$ 또는 $\mathrm{LOX}$ 저해제, 그리고 $\mathrm{PGE}_{2}$ 또는 $\mathrm{LTB}_{4}$ 의 생성량과의 상관관 계를 살펴 본 결과 $\mathrm{PGE}_{2}$ 또는 $\mathrm{LTB}_{4}$ 의 생성량의 감소가 전적으로 암세포증식 억제에 영향을 미친 것은 아님을 알 수 있었고, 세포 배지에 직접적으로 $\mathrm{PGE}_{2}$ 와 $\mathrm{LTB}_{4}$ 를 첨가해 준 경우에도 암세포 증식에는 영향을 미치지 않았다. 따라서 COX 또는 LOX 저해제는 eicosanoid 생 성 변화 외에 또 다른 기전을 통해 암세포 증식 억제에 관여할 가능성이 있다. 


\section{참 고 문 헌}

1. Eckhauser FE, Knol JA. Surgery for primary and metastatic colorectal cancer. Gastroenterol Clin North Am 1997;26:103129.

2. Lim CY, Kim JW, Song IH, Jin YJ, Rho IW, Park DK, Cho $\mathrm{JH}$, Choi SB. $b c l-2$ and p53 gene expression in colonic adenoma and carcinoma. J Korean Cancer Assoc 1998;30: 89-99.

3. National Nutrition Survey Report. Ministry of Health and Welfare, 1998.

4. Thun MH, Namboodiri MM, Calle EE, Flanders WD, Heath $\mathrm{CW}$. Aspirin use and reduced risk of fatal cancer. Cancer Res 1993;53:1322- 1327.

5. Giovannucci E, Timm EB, Stamfer MJ, Colditz GA, Ascherio A, Willett WC. Aspirin use and the risk for colorectal cancer and adenoma in male health professionals. Ann Intern Med 1994; $121: 241-246$.

6. Eberhart CE, Coffey RJ, Radhika A, Giardiello FM, Ferrenbach $\mathrm{S}$, DuBois RN. Up-regulation of cyclooxygenase-2 gene expression in human colorectal adenomas and adenocarcinomas. Gastroenterology 1994; 107:1183-1188.

7. Seibert K, Zhang Y, Leahy K, Hauser S, Masferrer J, Perkins $\mathrm{W}$, Lee L, Isakson P. Pharmacological and biochemical demonstration of the role of cyclooxygenase 2 in inflammation and pain. Proc Nati Acad Sci USA 1994;91:12013-12017.

8. Williams CW, DuBois RN. Prostaglandin endoperoxide synthase: why two isoforms? Am J Physiol 1996;270:G393-G400.

9. DuBois RN, Radhika A, Reddy BS, Entingh AJ. Increased cyclooxgenase-2 levels in carcinogen-induced rat colonic tumors. Gastroenterology 1996;110:1259-1262.

10. Williams CS, Luongo C, Radhika A, Zhang T, Lamps LW, Nanney LB, Beauchamp RD, DuBois RN. Elevated cyclooxygenase-2 levels in Min mouse adenomas. Gastroenterology 1996; 113:1134-1140.

11. Kawamori T, Rao CV, Seibert K, Reddy BS. Chemopreventive activity of celocobix, a specific cyclooxygenase-2 inhibitor, against colon carcinogenesis. Cancer Res 1998;58:409-412.

12. Zimmermann KC, Sarbia M, Weber AA, Borchard F, Gabbert HE, Schror K. Cyclooxygenase-2 expression in human esophageal carcinoma. Cancer Res 1999;59:198-204.

13. Sheng H, Shao J, Morrow JD, Beauchamp RD, DuBois RN. Modulation of apoptosis and Bcl-2 expression by prostaglandin E in human colon cancer cells. Cancer Res 1998;58:362-366.

14. Bortuzzo C, Hanif R, Kashfi K, Staiano-Coico L, Shiff SJ, Rigas B. The effect of leukotrienes B and sekected HETEs on the proliferation of colon cancer cells. Biochim Biophys Acta 1996; 1300:240-246.

15. Denizot F, Lang R. Rapid colometric assay for cell growth and survival modification to the tetrazolium dye procedure giving improved sensitivity and reliability. J Immunological Methods 1986;89:27 1-277.

16. Calaluce R, Earnest DL, Heddens D, Einspahr JG, Roe D, Bogert CL, Marshall JR, Alberts DS. Effects of piroxicam on prostaglandin E2 levels in rectal mucosa of adenomatous polyp patients: a randomized phase Ilb trial. Cancer Epidemiol Biomarkers Prev 2000;9:1287-1292.

17. Earashi M, Noguchi M, Kinoshita K, Tanaka M. Effects of eicosanoid synthesis inhibitors on the in vitro growth and prostaglandin $\mathrm{E}$ and leukotriene B secretion of a human breast cancer cell line. Oncology 1995;52:150-155.

18. Ding XZ, Kuszynski CA, RL-Metwally TH, Adrian TE. Lipoxygenase inhibition induced apoptosis, morphological changes, and carbonic anhydrase expression in human pancreatic cancer cells. Biochem Biophys Res Commun 1999;266:392-399.

19. Moody TW, Leyton J, Martinez A, Hong S, Malkinson A, Mulshine JL. Lipoxygenase inhibitors prevent lung carcinogenesis and inhibit non-small cell lung cancer growth. Exp Lung Res 1998;24:617-628.

20. Noguchi M, Earashi M, Minami M, Miyazaki I, Tanaka M, Sasaki T. Effects of piroxicam and esculetin on the MDAMB-231 human breast cancer cell line. Prostaglandins Leukot Essent Fatty Acids 1995;53:325-329.

21. Hofmanova J, Musilova E, Kozubik A. Suppression of human cancer cell proliferation by lipoxygenase inhibition and gammaradiation in vitro. Gen Physiol Biophys 1996;15:317-331.

22. Parker J, Kaplon MK, Alvarez CJ, Krishnaswamy G. Prostaglandin $\mathrm{H}$ synthase expression is variable in human colorectal adenocarcinoma cell lines. Experimental Cancer Res 1997;236: 321-329.

23. Kim WH, Yeo M, Kim MS, Chun SB, Shin EC, Park JH, Park IS. Role of caspase-3 in apoptosis of colon cancer cells induced by nonsteroidal anti-inflammatory drugs. Int J Colorectal Dis 2000; 15:105-111.

24. Ogino M, Hisatomi H, Murata M, Hanazona M. Indomethacin suppresses the growth of colon 26, Meth-A and FM3A tumors in mice by reducing the prostaglandin E2 content and telomerase activity in tumor tissues. Jpn J Cancer Res 1999;90: 758-764.

25. Trifan OC, Smith RM, Thompson BD, Hla T. Overexpression of cyclooxygenase-2 induces cell cycle arrest. Evidence for a prostaglandin-independent mechanism. J Biol Chem 1999;274: 34141-34147. 